\title{
Airway and feeding problems in infants with Fairbairn-Robin triad deformities
}

\author{
Authors: \\ Susanna M. du Plessis ${ }^{1}$ \\ Hester J.S. van den Berg ${ }^{1}$ \\ Kurt W. Bütow ${ }^{1}$ \\ Christiaan F. Hoogendijk \\ Affiliations: \\ ${ }^{1}$ Department of \\ Maxillo-Facial and Ora \\ Surgery, University of \\ Pretoria, South Africa \\ Correspondence to: \\ Daleen du Plessis \\ Email: \\ daleen.duplessis@up.ac.za \\ Postal address: \\ PO Box 74179, Lynnwood \\ 0040, South Africa \\ Dates: \\ Received: 22 Dec. 2011 \\ Accepted: 11 July 2013 \\ Published: 20 Sept. 2013 \\ Republished: 28 Nov. 2013
}

How to cite this article: Du Plessis, S.M., Van den Berg, H.J.S., Bütow, K.W. \& Hoogendijk, C.F., 2013, 'Airway and feeding problems in infants with Fairbairn-Robin triad deformities', Curationis 36(1), Art. \#84, 9 pages. http://dx.doi.org/10.4102/ curationis.v36i1.84

\section{Note:}

Article republished with the source added to Figures 1, 2 , 3 and 4.

\section{Copyright:}

(C) 2013. The Authors.

Licensee: AOSIS

OpenJournals. This work

is licensed under the

Creative Commons

Attribution License.

Read online:

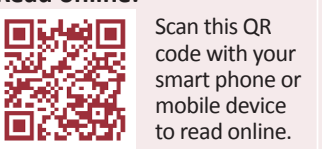

Background: The majority of patients with Pierre Robin sequence in the subdivision FairbairnRobin triad (FRT), are born with glossoptosis, retro-/micrognathia and cleft or agenesis of the palate leading to feeding difficulties and airway obstruction. There is limited literature on these problems, and on methods used to address them.

Objectives: Community nurses in the Facial Cleft Deformity Clinic evaluate associated airway obstruction and feeding problems and devise nursing interactions to address these. This retrospective study examined the incidence of airway and feeding difficulties in the neonatal, pre-surgical period, as well as the surgical and nutritional management of these infants.

Method: Retrospective records of 215 infants with FRT were examined and data on incidence, airway and feeding difficulties and surgical and nutritional management was collected. Descriptive statistics, including average and percentage values, were compiled.

Results: The incidence of FRT amongst the cleft palate patients was $6.0 \%$, with $37.7 \%$ of these having feeding difficulties. However, surgical interventions such as glossopexy $(5.6 \%)$, distraction osteogenesis $(0.9 \%)$ and tracheotomy $(2.3 \%)$ for airway management were seldom required. Most of the infants who had upper airway obstruction and feeding problems were handled by means of suction and drinking plates, along with additional specific feeding aids. This reduced airway obstruction in $70.6 \%$, and feeding problems in $62.4 \%$ of these infants.

Conclusion: Based on this study's finding the introduction of the suction and drinking plate and the use of specific types of feeding devices and surgical management can improve growth and development in infants with FRT.

\section{Introduction}

The triad of micrognathia (small mandible), cleft palate and upper airway obstruction due to glossoptosis is generally called the Pierre Robin sequence, and is a subdivision of the FairbairnRobin triad (FRT) (St-Hilaire \& Buchbinder 2000:1214-1256), which was first reported by Fairbairn (1846:280-281). These features can lead to major feeding difficulties, as the hard and soft palate cleft offers no support or seal for the tongue to act against when sucking and trying to extract milk from the breast or the teat. The glossoptosis also prevents efficient stroking of the teat during feeding and micrognathia leads to the tongue falling backwards causing airway obstruction. Some infants with FRT suffer from reflux, which itself may trigger vomiting and aspiration pneumonia.

A multidisciplinary team approach is necessary for the successful treatment of an infant with FRT. The basic team includes a maxillofacial and oral surgeon, orthodontist, paediatrician, speechlanguage pathologist and community nurse. Secondary team members include an ear, nose and throat (ENT) specialist, paedodontist, prosthodontist, clinical psychologist, social worker, dietician, human geneticist, paedo- or general anaesthesiologist, oral hygienist, audiologist and occupational therapist (Bütow 1995:13-15). Paediatricians are usually the first persons to encounter the newborn infant with FRT and will often recommend prolonged hospitalisation in a neonatal intensive care unit in order to manage the compromised airway and to ensure they get the necessary prescribed feeding regimen. They will also refer the parents to the facial cleft deformity (FCD) clinic within the first few days after birth for consultation and initial management by the multidisciplinary team. The orthodontist will place a suction and drinking plate to aid nutrition as well as to prevent the tongue from obstructing the nasal airway. The community nurses give parental guidance on the use of these devices and prescribe the most suitable feeding device and feeding method for each infant.

The community nurses (specially trained in the treatment of infants with facial cleft deformities, including FRT) assess each individual infant's feeding progress and refer the parents alternatively 
to a dietician for a special milk formula in cases of inadequate weight gain. A speech and language therapist, who might also be a feeding specialist, may be consulted for infants with an impaired sucking action to introduce oral stimulation therapy. These nurses play a pivotal role in coordinating the treatment plan of each individual infant with FRT with the rest of the multidisciplinary team and the parents.

They also lecture visiting paediatric nursing students on specialised feeding protocols, managing airway and breathing difficulties, as well as the pre- and post-surgical nursing management of the infant with FRT. These students visit the FCD clinic for their practical exposure or clinical learning experiences. Learning events are structured according to the unique educational needs of neonatal intensive care unit (NICU) nurses, paediatric nurses and other child nurse practitioners working in the clinical areas as well as community clinics where these infants with FRT are treated. Learning events include lectures, informal teaching, demonstrations and case discussions.

\section{Definitions}

A cleft refers to a pathologic fissure derived from a failure of parts to fuse during embryonic development. Glossoptosis is the downward displacement or retraction of the tongue. This prevents efficient stroking of the teat and breast during feeding causing insufficient intake of milk. Micrognathia refers to retrognathia or abnormal smallness of the mandible resulting in retraction of the tongue. The neonatal period defines the first 4 weeks after birth whilst perinatal relates to the period shortly before and after birth; from the 29th week after gestation to 1-4 weeks after birth.

\section{Literature review}

The first report of micrognathia, cleft palate and upper airway obstruction due to glossoptosis was documented by Fairbairn (1846). He published a description of two cases where the triad glossoptosis, micrognathia and cleft palate were present, and suggested a glossopexy as the best neonatal treatment strategy. Later, Robin reported on only two of the conditions associated with this triad, namely, the glossoptosis and micrognathia, and called this subdivision the Siebold-Robin sequence (Meyer \& Schwalbe 1920:405-41; Robin 1923: 235-237, 1934:541-547). He never observed the additional cleft palate. Today, the majority of authors recognise the Pierre Robin sequence, with a subdivision called the FairbairnRobin triad (FRT) that has the micrognathia, glossoptosis and a cleft palate (Bütow, Hoogendijk \& Zwahlen 2009: 1112-1118; Elliott, Studen-Pavlovich \& Ranalli 1995:106-111; Fairbairn 1846:280-281; Figueroa, Glupker \& Fitz 1991:425-434; Hoogendijk \& Bütow 2008:S15-O.059; Laitinen \& Ranta, 1992:177-183; St-Hilaire \& Buchbinder 2000:1214-1256).

\section{Background}

The Facial Cleft Deformity (FCD) Clinic of the University of Pretoria was founded in August 1983. It is dedicated to the treatment of patients with facial cleft deformities. It is the largest such clinic in South Africa and Africa, with patients being referred from a wide variety of disciplines and areas throughout the country and even further afield. The clinic has treated more than 3575 patients over the last 28 years, which has provided the multidisciplinary team with vast experience and expertise. The incidence of infants with FRT in this clinic for cleft lip/or palate was $6.0 \%$, in comparison with the rare insidence of FRT in the general population of $1 / 8500(0.01 \%)$, according to Lidsky, Lander and Sidman (2008:120-123).

\section{Objectives of the study}

This study was a patient record audit of all the patients with FRT who were seen and treated at the University of Pretoria FCD Clinic between 1983 and 2011. It aimed to:

- identify the number of patients with FRT that presented at the clinic over this 28 year period

- evaluate the characteristics of the palatal deformity, noting any associated airway obstruction and feeding problems

- analyse the nursing interactions provided in order to optimise growth of the infant with FRT

- support the surgical management with nursing care, the sequence of palatal reconstruction followed and the resultant outcomes.

The outcome of this study may be of significant value to all the disciplines involved in treating infants with FRT, since none of the mentioned objectives have previously been studied extensively or well documented.

\section{Materials and methods}

This study consisted of a patient record review to measure the quality of the pre-surgical nursing care and post-surgical nursing care provided to infants with FRT. Markers of quality nursing care were identified and emphasised as important for future use in relation to surgical care. Permission was gained from the Head of the University of Pretoria Facial Cleft Deformity Clinic to access patient files. Parents had all previously given written consent to have their children's files perused (Appendix 1). Anonymity was maintained by numbering the files and ensuring that no names or identifying features were recorded. All the data were collected by two researchers and confidentiality was guaranteed. The clinical charts of cleft lip and palate patients seen at the clinic from 1983 to 2011 were accessed and analysed. A total of 3575 patient's files were retrieved. Demographic data including age, sex, and racial group were recorded. In addition, the characteristics of the palatal deformity with associated airway obstruction or feeding problems during the perinatal period, initial nursing and surgical management as well as the sequence of the palatal reconstruction and their outcomes were analysed.

\section{Results}

Of the 3575 records, there were 215 (6\%) infants with the FRT of glossoptosis, micrognathic (or retrognathic) mandible (Figure 1a) and cleft palate (Figure 1b). 
These 215 patients formed the basis of the analysis that follows. The isolated soft palate cleft (sP) was diagnosed in $23(10.7 \%)$ patients, and a combined hard and soft palate cleft (hPsP) was observed in 192 (89.3\%). Severe micrognathia (Figure 1a) with severe microglossia occurred in patients who had either complete wide isolated sP clefts or a nearly absent sP. The glossoptosis may result from the tongue being directly positioned into the cleft and oro-nasopharynx, or from a tongue folded lengthwise and interpositioned between the cleft edges. The length of the hP cleft was inversely related to the severity of the micrognathia and microglossia. The prevalence of patients with FRT within each racial group of the cleft population was: African: $2.5 \%$, Coloured (mixed race): $2.0 \%$, Indian descent: $7.3 \%$, European descent: $7.7 \%$. There were 96 males and 119 females, i.e. a gender ratio of $44.7 \%-55.3 \%$.

\section{Airway obstruction}

The prone and lateral position relieves upper airway obstruction in most infants with FRT, whilst the supine
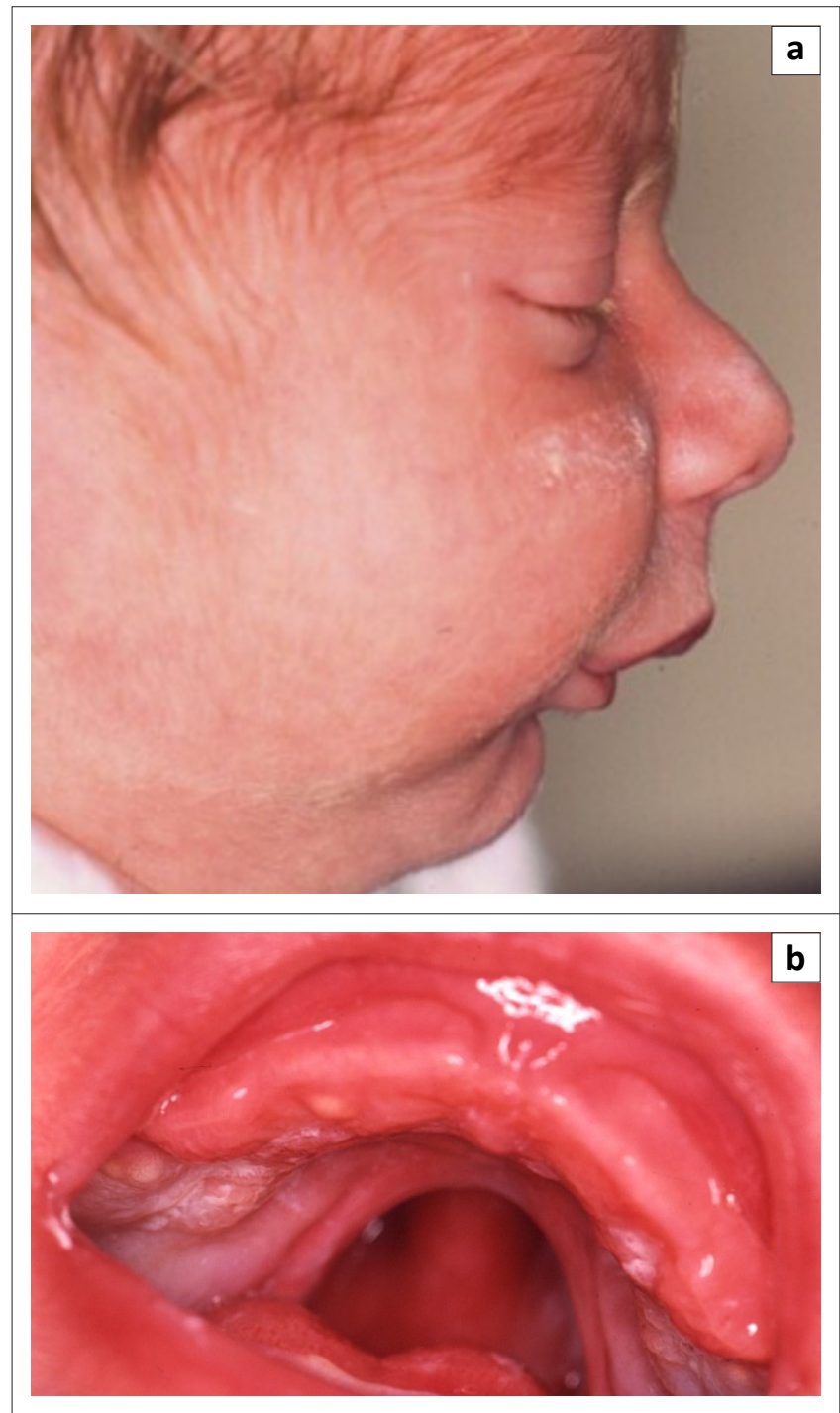

Source: Bütow, K.W., 1984, 'Treatment of cleft lip and palate. Part II: The jaw-orthognathic suction and drinking plate', Journal of the Dental Association of South Africa 39, 331-334

FIGURE 1: (a) Profile of a child with a FRA. (b) Pre-operative appearances of the hard and soft palate cleft. position may considerably aggravate apnoea, caused by the glossoptosis. Parental awareness of the infant placing the tongue in the cleft, causing airway obstruction and cyanosis, is critical. Parents are advised that airway obstruction can be relieved by placing the infant immediately in the prone position. After birth, the initial management consisted of the manufacturing of a suction and drinking plate (Figure 2a and Figure 2b) (Bütow 1984:331-334), which was used in $170(79.1 \%)$ cases. In $152(70.6 \%)$ infants with FRT, the plate therapy was sufficient to relieve the glossoptosis and thus the upper airway obstruction. The plate was positioned as soon as possible after birth to assist in the repositioning of the tongue away from the cleft and to separate the nasal cavity from the oral cavity. Plate therapy is not always required in an infant where ankyloglossia (active lingual frenulum) with no glossoptosis are present. However, one case with an ankyloglossia required a glossopexy (tongue-alveolus fusion or tongue-lip fusion) (Argamaso 1992:232-238; Denny, Amm \& Schaefer 2004:819-823) for the relief of upper airway obstruction. In 12 (5.6\%) of the infants with FRT, a glossopexy was also required, as the plate therapy did not
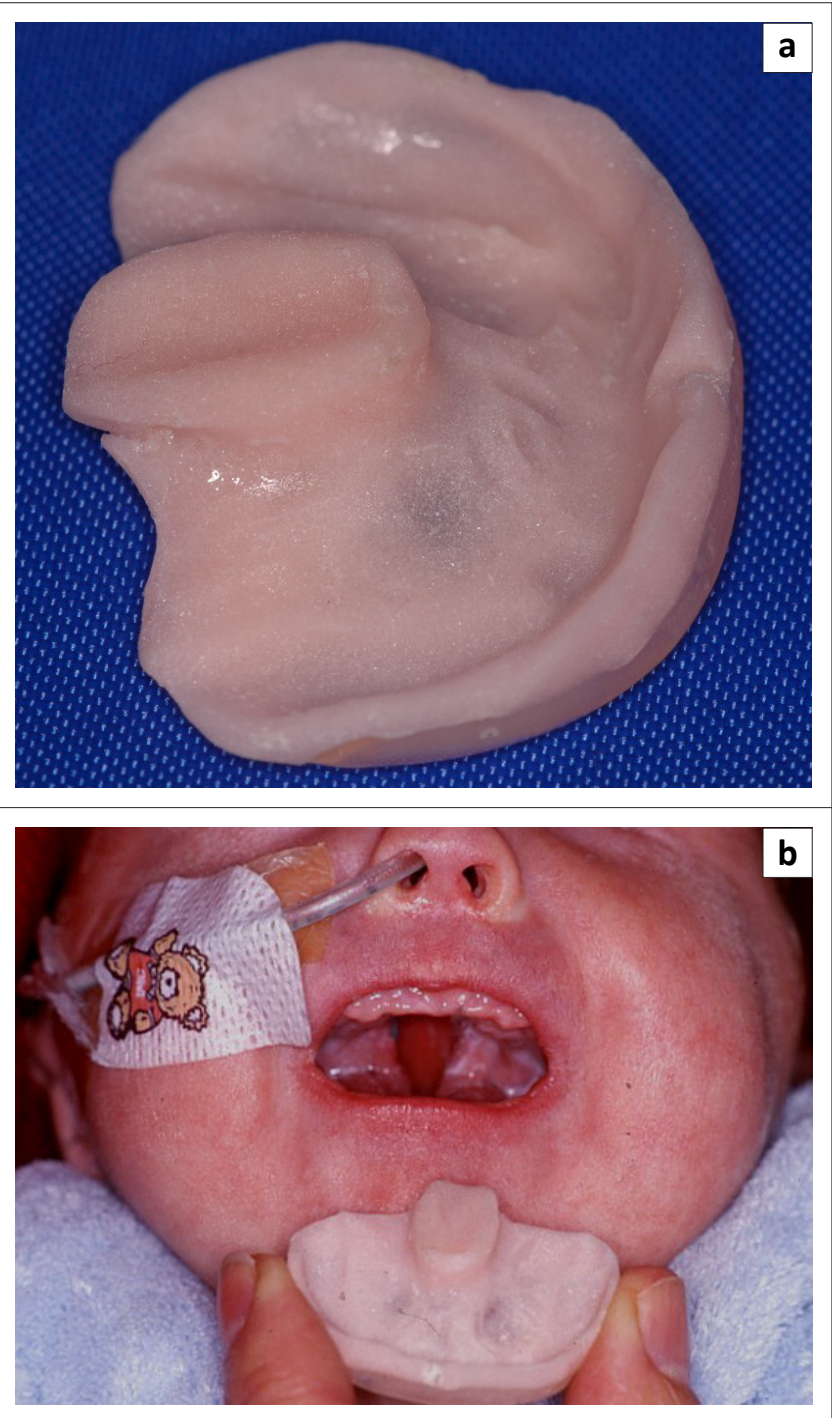

Source: Bütow, K.W., 1984, 'Treatment of cleft lip and palate. Part II: The jaw-orthognathic suction and drinking plate', Journal of the Dental Association of South Africa 39, 331-334

FIGURE 2: (a) Suction and drinking plate for an infant with a FRA. (b) Before positioning of the plate. 
relieve the airway obstruction and the persistent glossoptosis with apneoa, and one infant had to receive a tracheotomy at a later stage.

Persistent airway breathing problems combined with feeding problems, lead to excessive burning of calories, which in turn compromises weight gain (Reid, Kilpatrick \& Reilly 2006:207-209). Eight (3.7\%) neonates with FRT had to receive long-term naso-endotracheal intubation and, as mentioned, one later had a tracheotomy. One of the patients with FRT received distraction osteogenesis for apneoa (Burstein \& Williams 2005:61-67; Denny 2004:221-229). In two cases with FRT, a tracheotomy was performed immediately after birth due to severe respiratory distress. These two were patients with syndromic-FRT, diagnosed with Stickler syndrome. In total, five $(2.3 \%)$ tracheotomies were performed.

\section{Feeding problems}

Specific information on feeding and feeding problems was recorded in 183 (85.1\%) infants with FRT. Feeding difficulties were recorded in $81(37.7 \%)$ infants. Thirty-five cases $(16.3 \%)$ had an ankyloglossia where $15(18.75 \%)$ of these cases with ankyloglossia presented with persistent feeding difficulties and six only had relief from feeding difficulties after surgical closure of the soft palate. As such, the feeding plate therapy did not help in these six infants with FRT.

In untreated infants with FRT, the tongue cannot be positioned naturally, as it has no palatal support from the u-shaped hPsP opening (Figure $1 \mathrm{~b}$ ). The abnormal position of the tongue in the naso-oropharynx, with glossoptosis, prevents the efficient stroking of the teat and the natural extraction of milk. Prolonged feeding time due to intermittent apneoa results in less fluid intake. Should additional reflux occur, it may result in vomiting and even aspiration pneumonia. Each infant with FRT was assessed individually by a community health nurse from the Cleft Lip and Palate Clinic and the most effective feeding method and aids were ascertained (Figure $3 \mathrm{a}$ to Figure 3d). The custom-made feeding plate was placed in the palate and the tongue was coaxed into an inferior and anterior position. Partial closure of the $\mathrm{hP}$ and sP cleft facilitated feeding and prevented nasal regurgitation of food. Various additional feeding aids such as soft bottles (Figure $3 a$ ) and special teats (Figure $3 b$ to Figure $3 d$ ) are available. However, only some suit the specific needs of an infant with FRT. The specific teat, with its air valve (Figure 3c), softness (Figure $3 b$ to Figure $3 d$ ), length (Figure $3 b$ ), and differences in hardness between the stroking part and the non-stroking part, as well as the size of the crosscut or Y-cut opening (Figure 3c) are carefully chosen for the individual infant with FRT.

During feeding, the infant with FRT must be cradled with his or her body at an approximate angle of $45^{\circ}$ horizontally or vertically. This should prevent nasal regurgitation and possible reflux of fluid into the Eustachian tubes. Pacifiers are recommended, as continuous sucking stimulates anteroposterior movement of the mandibular micrognathia, which
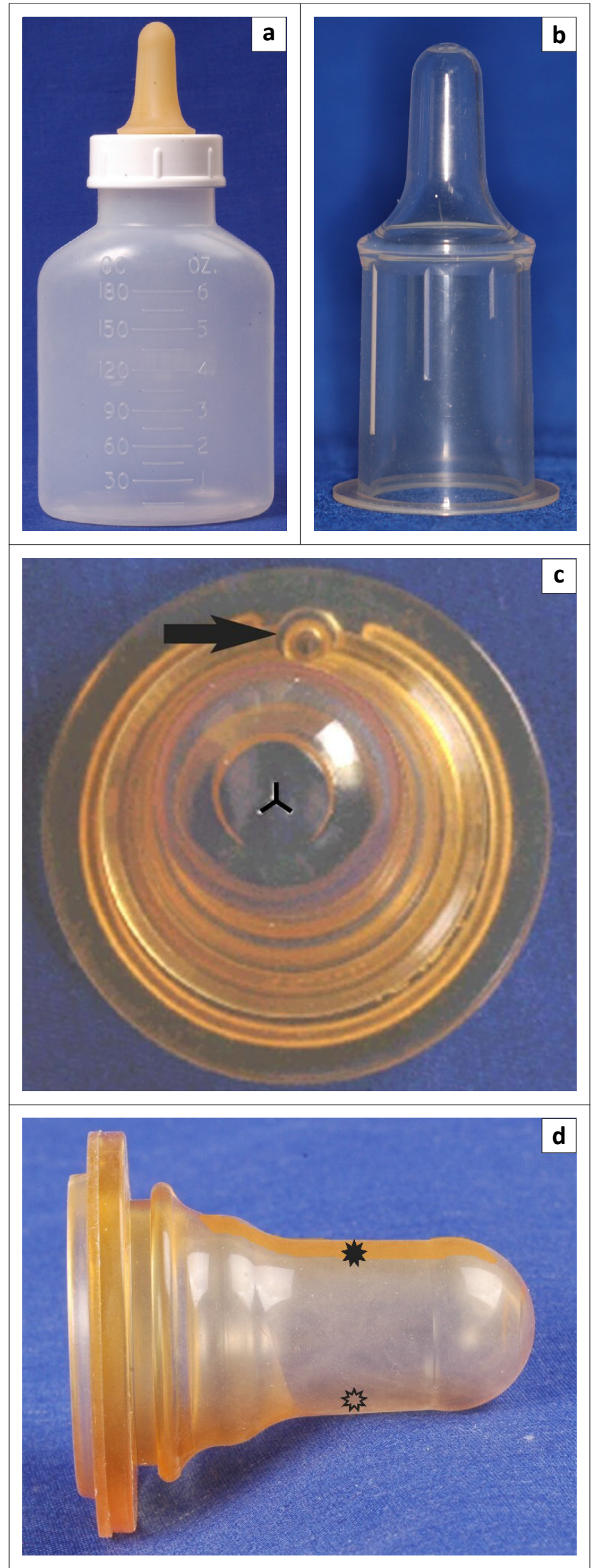

Source: Bütow, K.W., 1984, 'Treatment of cleft lip and palate. Part II: The jaw-orthognathic suction and drinking plate', Journal of the Dental Association of South Africa 39, 331-334 Black Arrow, air valve; black star, harder non-stroking part of the teat, e.g. the upper part of the teat; see through star, softer stroking part of the teat,e.g. the bottom part of the teat.

FIGURE 3: Feeding aids: (a) soft squeezable bottle, (b) teat: length and width flow indication, (c) Y-crosscut opening, (d) teat with hard top and soft bottom. 
again facilitates the enlargement of the mandible (Vegter, Hage \& Mulder 1999:154-157), with improved feeding and airway due to an enlarged mandible and tongue. However, this 'catch-up growth' should not be assumed (Daskalogiannakis, Ross \& Tompson 2001:280-285; Shprintzen \& Singer 1992: 109-114;). Catch-up growth occurred in 44-120 (36.7\%) patients with FRT. Oligohydramnios was recorded in 21-133 $(15.8 \%)$ and polyhydramnios in 5-133 (3.7\%), which might have influenced the catch-up growth aspect positively.

Thirty-seven (21.8\%) of the 170 infants with FRT who received a suction and drinking plate had no relief of their feeding difficulties. These patients were fed with nasogastric tubes and $12(5.9 \%)$ of them required gastrostomies. The plate therapy prevented feeding problems in $62.4 \%$ of the reported cases.

Six patients suffered from both respiratory and feeding difficulties, in spite of the plate therapy. The severe upper airway obstruction was managed by means of prolonged nasopharyngeal intubation (8), or glossopexy (12), or distraction osteogenesis (2), or tracheotomy (5), and the persistent severe feeding problem was treated by means of a gastrostomy (12).

\section{Palatal reconstruction}

The sP cleft was closed at seven months of age and the hP repair was done at 18 months of age. A two-stage procedure was performed in $132(63.0 \%)$ patients (Figure 1b, Figure 4a and Figure $4 \mathrm{~b}$ ). The two stage procedure allows continuous air flow through the nasal and oral cavities via the open hard palate cleft (Figure 4a). The tongue, however, is permanently repositioned inferior-anteriorly after the reconstructed soft palate. Palatal reconstruction of the sP cleft only, which could also sometimes include reconstruction of the short type hP ( $5 \%-15 \%$ in length only) cleft, is a one-stage procedure, and was performed in $61(28.6 \%)$ patients.

\section{Ethical considerations}

Permission was gained from the head of the University of Pretoria's FCD Clinic to access patient files. There were no potential physical, psychological or disclosure risks to the infants or the parents in this study because only data was used. The outcome of this study may benefit infants and parents in future by educating medical disciplines in managing feeding problems and airway obstruction in infants with FRT. Retrospective data from patient's files was retrieved and used for this study. On admission parents or patients are informed that data, photographical material and models may be used for teaching, research and publication and they are requested to sign consent for this. Refusal to sign will not impact on their treatment.

\section{Data protection}

The University of Pretoria's policy of protection of intellectual property applies. For ethical reasons, anonymity was maintained and all patients' photographs were taken in such
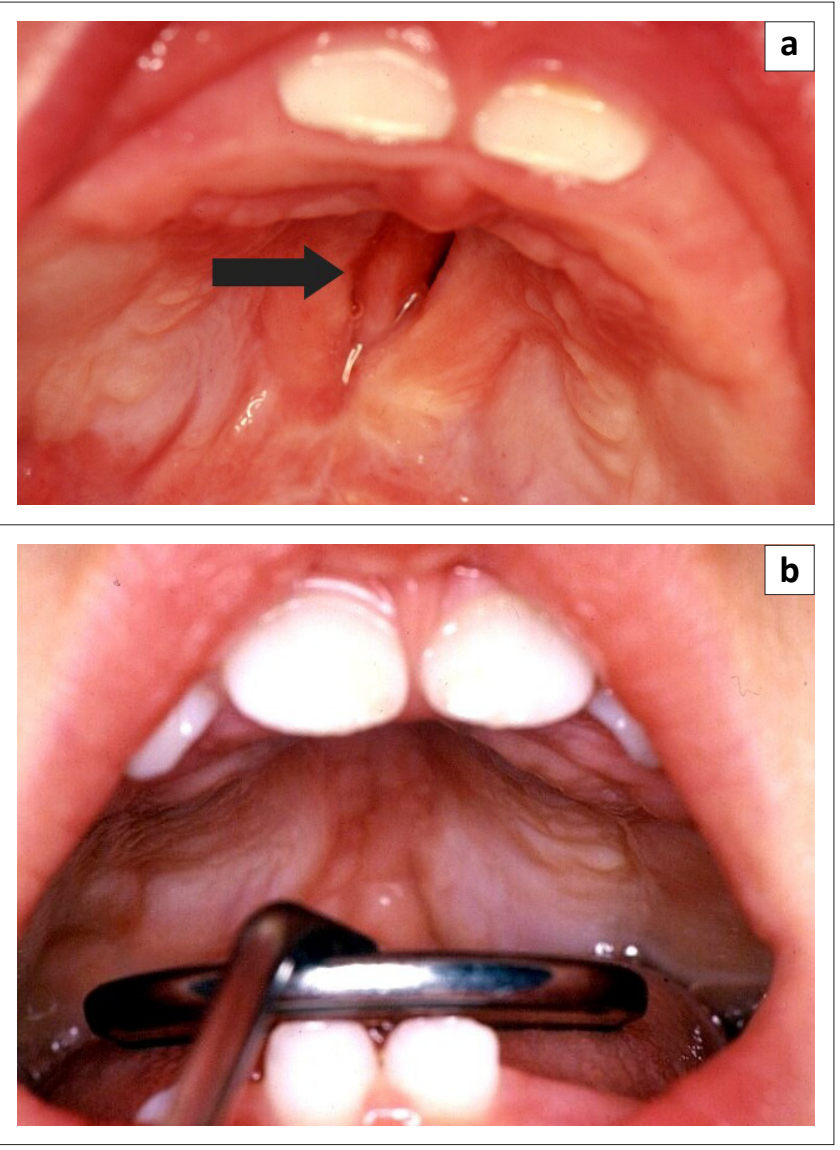

Source: Bütow, K.W., 1984, 'Treatment of cleft lip and palate. Part II: The jaw-orthognathic suction and drinking plate', Journal of the Dental Association of South Africa 39, 331-334

FIGURE 4: (a) Post-operative appearances of the soft palate and narrowing of hard palate cleft after 18 months, before the closure of the hard palate cleft. (b) Postoperative appearances after construction.

a way that did not allow any possibility of identification of the subject. Parents sign documentation concerning the treatment of the infants and no names or file numbers were identified. Data is stored in a secure office and only involved staff members have access to patient files.

\section{Discussion}

According to Lidsky et al. (2008:120-123), the incidence of FRT in the general population is rare $1 / 8500(0.01 \%)$. The incidence of infants with FRT in this clinic for cleft lip and/ or palate was $6.0 \%$. Nowadays, the majority of authors describe the FRT appearance as a triad of airway obstruction or glossoptosis, micrognathia or retrognathia and cleft palate (Amaratunga 1988:451-458; Bütow et al. 2009:1112-1118; Elzen, Semmekrot \& Bongers 2001:47-53; Figueroa et al. 1991:425-434; Holder-Espinasse, Abadie \& Cormier-Daire 2001:588-590; Paletta, Dehghan \& Hutchinson 1994:1301-1303; Taylor 2000:125-130).

An epidemiological survey reported the incidence of FRT within the cleft population as 10\% (Taylor 2000:125-130). The study population of 215 patients with FRT, on which the present article is based, represents the largest number of patients ever included in a publication, and in this group, the incidence was $6.0 \%$ in the overall facial cleft deformity database of 3575 . The $\mathrm{u}$-shaped cleft with the tongue 
positioned in the cleft and nasopharynx or naso-oropharynx, represents the typical clinical picture of glossoptosis. However, the cleft may also be narrow with a length wise upwards folded tongue positioned in the cleft, also causing glossoptosis. In the wide or narrow cleft with a short or almost aplastic sP, the tongue is displaced more horizontalposteriorly into the nasopharynx and/or naso-oropharynx, also resulting in glossoptosis. The cleft type of the $\mathrm{sP}$ or hPsP is therefore not at all important, only the presence of a palatal cleft. The overall male to female ratio for FRT in the study was $44.7 \%-55.3 \%$. In contrast, the male to female ratio in the general cleft population of this database was $53.4 \%-46.6 \%$.

Upper airway obstruction due to glossoptosis is a major problem in neonates with FRT (Paletta et al. 1994:1301-1303). Some authors suggest the use of nasopharyngeal tubes to secure the airway passage, but only one report mentioned the combination of airway obstruction and feeding problems (Masters, Chang \& Harris 1990:186-187). Generally, very little has been published on the approach to feeding difficulties (Rayatt, Tatman \& Slator 2004:176-179; Wagener, Rayatt \& Tatman et al. 2003:180-185; Whitaker, Koron \& Oliver et al. 2003:272-274) The present article draws attention to the importance of the custom-made suction and drinking plate in the treatment of upper airway and feeding problems. In the vast majority of cases, this special plate prevents the microglossia from obstructing nasal airways and hinders glossoptosis. The plate can be lengthened or extended inferiorly for the partial soft palate cleft, thereby preventing nasopharyngeal obstruction in most cases.

Ankyloglossia in patients with FRT was observed in 16.3\% of these patients. Feeding problems were observed in a number of ankyloglossic infants (18.5\%). The natural attachment of the short lingual frenulum to the alveolar ridge is believed to prevent the tongue from moving into the cleft, and/or to hinder the tongue from being positioned in the naso-oropharynx. However, unexpected feeding problems persisted in some cases $(16.0 \%)$, even with plate therapy.

Rayatt and co-workers stated that only three of 22 (13.6\%) babies with nasopharyngeal tubes were able to be fully bottle fed after a mean hospitalisation stay of 60 days (Rayatt et al. 2004:176-179). The advantage of using the special suction and drinking plate for infant with FRT lies in the creation of an artificial anatomical division between the oral and nasal cavities. Airway and feeding problems mean longer hospitalisation periods. The plate therapy resolved some of the severe feeding difficulties (44 of 81 cases; $54.3 \%$ ). Only 8 (9.9\%) patients with FRT required longer hospitalisation time (30-60 days) for the combination of severe airway obstruction and feeding problems.

There was a need for glossopexy and tracheotomy in $27.2 \%$ and $3.7 \%$ of infants, with FRT respectively (Kirschner, Low \& Randall 2003:13-18). Some clinicians used tracheotomies as a standard approach to secure the airway $(18.2 \%, 21.7 \%$, and $41.3 \%$ respectively) in their reported cases with FRT (Bütow 1995:13-15; Elliott et al. 1995:106-111; Smith \&
Senders 2006:319-324). In this study population, glossopexy, and/or distraction osteogenesis and/or tracheotomy were used as the last option, and then only until the first surgical reconstruction procedure. Only $8.8 \%$ of the infants with FRT required these procedures (glossopexy 5.6\%; distraction osteogenesis $0.9 \%$; tracheotomy $2.3 \%$ ). Glossopexy often results in immediate improvement of the airflow through the upper airway passage.

Hard and soft palate cleft (hPsP) reconstruction is performed at different stages. The $\mathrm{sP}$ cleft is first closed at seven months of age (Bütow 1995:13-15; Hoogendijk et al. 2008:S15-O.059). The wide opening of the hP cleft contributes to maintenance of the airway passage via the nasal cavity. During the next 11 months the tongue adopts a more anterior-inferior position, after which the $\mathrm{hP}$ cleft is closed at 18 months of age. During the preceding 11 months, the hP cleft becomes significantly narrower and anatomically more normal (Figure 4a), thereby assisting in oral and nasal airway passage adaptation for normal airflow. These adaptive mechanisms are very important in reducing any post-surgical upper airway problems.

There are limited systematic reviews of feeding problems in the population with FRT and very few publications on early feeding, nutrition (Augarten et al. 1990:105-108) and assisted feeding methods (Nassar et al. 2006:54-60; Singer \& Sidoti 1992:220-223). One publication details various feeding mechanisms and aids (Reid 2004:268-278). However, with the plate therapy, as well as with all the different feeding aids mentioned, each infant with FRT has to be individually assessed and the feeding aids repeatedly changed until the optimal feeding method is established. Feeding difficulties presented in $50 \%$ and $54 \%$ of FRT patients reported in the literature (Elliott et al. 1995:106-111; Elzen et al. 2001: 47-53), which is slightly higher than in this study (37.7\%). Furthermore, it has been previously reported that between $25.4 \%$ (Lidsky et al. 2008:120-123) and more than 50\% of the infants with FTR require gastrostomy tubes to overcome feeding difficulties. (Denny et al. 2004:819-823). However, in this study, the procedure was only used in only $12(5.6 \%)$ patients not responding to plate therapy.

\section{Limitations of the study}

The results were calculated on those aspects that were documented between 1983 and 2011 in the patient records.

\section{Recommendations}

From this study, a nursing care plan for an infant with FRT can be compiled for implementing in all NICUs, paediatric wards and well baby clinics. Markers in the nursing plan include the prone and lateral positioning, management of special feeding devices and counselling on specific feeding methods. Feeding methods include oral feeding with special bottles and teats as previously described. Severe feeding difficulties can be treated by means of nasogastric tube feeding or gastrostomy feeding. 
In both the NICU and paediatric wards a custom-made wedge pillow can be used to facilitate the prone position in order to prevent the tongue from obstructing the airway. The adjustable angle of the wedge pillow can also prevent shortening of the rhomboid muscles and hyperextension of the major pectoral muscles. Parents and other caregivers can also be educated on how to use a wedge pillow effectively at home after discharge.

Continuous evaluation by the community nurses should be implemented by means of telephonic contact and visits to assess whether the learning events result in improved skills and knowledge of all the role-players in the clinical setting as well as the community. Parental education and knowledge can lead to shorter hospitalisation, a successful feeding programme and stabilisation of the airway.

Infants that experience prolonged feeding difficulties after discharge from NICU may be referred to day care centres with a speech and language therapist that can attend to specific feeding problems.

\section{Conclusion}

FRT as a well-known neonatal syndrome was named after Pierre Robin, generally called Pierre Robin sequence (PRS), yet the triad was first detected and described in detail 77 years earlier by Fairbairn. The FRT, as a subdivision of the PRS, includes a triad of glossoptosis, wide hPsP cleft or very atrophic soft palate, and a micrognathic or retrognathic mandible. The tongue is in the cleft or displaced posterior to the palate, and a concomitant microglossia with a micrognathic mandible is also present. The more micrognathic the mandible, the smaller the tongue and the more posteriorly the tongue may be positioned with a typical glossoptosis. The incidence, which varies between the different racial groups and the complication rate of FRT within this cleft study population is lower than previously documented. In this report, the importance of a suction and drinking plate, the specific types of feeding devices and their utilisation, as well as the sequence of surgical management for the hard and soft palate cleft are emphasised. This treatment strategy has the advantages of decreasing any additional surgical interventions and hospitalisation during the pre- and post-surgical period. The immediate postnatal treatment must be individually assessed, since particular difficulties are experienced.

Published data, patient records and experience from the 28 years of the clinic's existence are being used to compile an individual nursing plan to inform role players (including parents and a multidisciplinary team) of the feeding and airway management and surgery of infants with FRT to obtain optimal growth and development.

\section{Acknowledgements}

The authors wish to acknowledge the help of Professor L.M. Sykes in editing the manuscript.

\section{Competing interests}

The authors declare that they have no financial or personal relationship(s) which may have inappropriately influenced them in writing this article.

\section{Authors' contributions}

S.M.d.P. (University of Pretoria) wrote the manuscript. H.J.S.v.d.B. (University of Pretoria), K.W.B. (University of Pretoria) and C.F.H. (University of Pretoria) were co-authors.

\section{References}

Amaratunga, N.A., 1988, 'A comparative clinical study of Pierre Robin syndrome and isolated cleft palate', British Journal of Oral and Maxillofacial Surgery 27, 451458. http://dx.doi.org/10.1016/\$0266-4356(89)80002-6

Argamaso, R.V., 1992, 'Glossopexy for upper airway obstruction in Robin Sequence', The Cleft Palate-Craniofacial Journal 29, 232-238. http://dx.doi.org/10.1597/15451569(1992)029<0232:GFUAOI>2.3.CO;2

Augarten, A., Sagy, M., Yahav, J. \& Barzilay, Z., 1990, 'Management of upper airway obstruction in the Pierre Robin syndrome', British Journal of Oral and Maxillofacia Surgery 28,105-108. http://dx.doi.org/10.1016/0266-4356(90)90133-6

Burstein, F.D. \& Williams, J.K., 2005, 'Mandibular distraction osteogenesis in Pierre Robin sequence: Application of a new internal single-stage resorbable service', Plastic and Reconstructive Surgery 115, 61-67. PMid:15622233

Bütow, K.W., 1984, 'Treatment of cleft lip and palate. Part II: The jaw-orthognathic suction and drinking plate', Journal of the Dental Association of South Africa 39, 331-334. PMid:6592798

Bütow, K.W., 1995, 'The multidisciplinary approach and the therapy protocol', Treatment of facial cleft deformities, p. 13-15, Ishiyaku EuroAmerica Inc., Tokyo.

Bütow, K.W., Hoogendijk, C.F. \& Zwahlen, R.A., 2009, 'Pierre Robin sequence: appearances and 25 years of experience with an innovative treatment protocol', Journal of Pediatric Surgery 44, 1112-1118. http://dx.doi.org/10.1016/j.jpedsurg.2009.04.018, PMid:19944218

Daskalogiannakis, J., Ross, B. \& Tompson, B.D., 2001, 'The mandibular catch-up growth controversy in Pierre Robin sequence', American Journal of Orthodontics and Dentofacial Orthopedics 120, 280-285. http://dx.doi.org/10.1067/mod.2001.115038, PMid:11552127

Denny, A.D., Amm, C.A. \& Schaefer, R.B., 2004, 'Outcomes of tongue-lip adhesion for neonatal respiratory distress caused by Pierre Robin sequence', Journal of Craniofacial Surgery 15, 819-823. http://dx.doi.org/10.1097/00001665-200409000-00023, PMid:15346025

Denny, A.D., 2004, 'Distraction osteogenesis in Pierre Robin neonates with airway obstruction', Journal of Clinical Pediatric Dentistry 31, 221-229. http://dx.doi. org/10.1016/S0094-1298(03)00131-7

Elliott, M.A., Studen-Pavlovich, D.A. \& Ranalli, D.N., 1995, 'Prevalence of selected pediatric conditions in children with Pierre Robin sequence', Journal of Pediatric Dentistry 17, 106-111. PMid:7603903

Elzen, A., Semmekrot, B., Bongers, E., Huygen, P.L.M. \& Marres, H.A.M., 2001, 'Diagnosis and treatment of the Pierre Robin sequence: Results of a retrospective clinical study and review of the literature', European Journal of Pediatrics 160, 47-53. $\mathrm{http}: / / \mathrm{dx}$.doi.org/10.1007/s004310000646, PMid:11195018

Fairbairn, P., 1846, 'Suffocation in an infant from retraction of the base of the tongue', Monthly Journal of Medical Science 6, 280-281.

Figueroa, A.A., Glupker, T.J., Fitz, M.G. \& BeGole, E.A., 1991, 'Mandible, tongue, and airway in Pierre Robin sequence: A longitudinal cephalometric study', The Cleft Palate-Craniofacial Journal 28, 425-434. http://dx.doi.org/10.1597/15451569(1991)028<0425:MTAAIP>2.3.CO;2

Holder-Espinasse, M., Abadie, V., Cormier-Daire, V., Beyler, C., Manach, Y., Munnich, A et al., 2001, 'Pierre Robin sequence: A series of 117 consecutive cases', Journal of Pediatrics 139, 588-590. http://dx.doi.org/10.1067/mpd.2001.117784, PMid:11598609

Hoogendijk, C.F. \& Bütow, K.W., 2008, 'Fairbairn-Robin appearance: A controversial syndrome, 171 cases', Journal of Cranio-Maxillofacial Surgery 36, S15 (0.059).

Kirschner, R.E., Low, W., Randall, P., Bartlett, S.P., McDonald-McGinn, D.M., Schultz, P.J. et al., 2003, 'Surgical airway management in Pierre Robin sequence: Is there a role for tongue-lip adhesion?', The Cleft Palate-Craniofacial Journal 40, 13-18. http:// dx.doi.org/10.1597/1545-1569(2003)040<0013:SAMIPR>2.0.CO;2

Laitinen, S.H. \& Ranta, R.E., 1992, 'Cephalometric measurements in patients with Pierre Robin syndrome and isolated cleft palate', Journal of Plastic Surgery and Hand Surgery 26, 177-183. http://dx.doi.org/10.3109/02844319209016010

Lidsky, M.E., Lander, T.A. \& Sidman, J.D., 2008, 'Resolving feeding difficulties with early airway intervention in Pierre Robin sequence', The Laryngoscope 118, 120-123. http://dx.doi.org/10.1097/MLG.0b013e31815667f3, PMid:17975504

Masters, I.B., Chang, A.B., Harris, M. \& O'Neil, M.C., 1990, 'Modified nasopharyngeal tube for upper airway obstruction', Archives of Disease in Childhood 80, 186-187. http://dx.doi.org/10.1136/adc.80.2.186 
Meyer, R. \& Schwalbe, E., 1920, 'Beiträge zur Kasuik und zur Kritik der Mikrognatien', Studien Pathol Entwickl (Jena),11, 405-411.

Nassar, E., Marques, I.L., Trindade, A.S. \& Bettiol H., 2006, 'Feeding-facilitating techniques for the nursing infant with Robin sequence', The Cleft Palate-Craniofacial Journal 43, 54-60. http://dx.doi.org/10.1597/04-018.1, PMid:16405375

Paletta, C.E., Dehghan, K., Hutchinson, R.L. \& Klaw, B., 1994, 'A fall of the base of the tongue considered as a new cause of nasopharyngeal respiratory impairment: Pierre Robin sequence, a translation', Plastic and Reconstructive Surgery 93, 1301-1303. $\mathrm{http}: / /$ dx.doi.org/10.1097/00006534-199405000-00032

Rayatt, S., Tatman, A., Slator, R.\& Gornall, P., 2004, 'Letter to the editor: Re: Whitaker et al., Effective management of airway in Pierre Robin syndrome', British Journal of Oral and Maxillofacial Surgery 42 (2), 176-179. http://dx.doi.org/10.1016/ S0266-4356(03)00266-3

Reid, J., 2004, 'A review of feeding interventions for infants with cleft palate', The Cleft Palate-Craniofacial Journal 41, 268-278. http://dx.doi.org/10.1597/02-148.1, PMid:15151444

Reid, J., Kilpatrick, N. \& Reilly, S., 2006, 'A prospective, longitudinal study of feeding skills in a cohort of babies with cleft conditions', The Cleft Palate-Craniofacia Journal 43, 207-209. http://dx.doi.org/10.1597/05-172, PMid:17105331

Robin, P., 1923, 'La glossoptose. Son diagnostic, ses conséquences, son traitement' [Glossoptosis. its diagnosis, its consequences, its treatment] Bulletin de l'Académie Nationale de Médecine 43, 235-237.

Robin, P., 1934, 'Glossoptosis due to atresia and hypotrophy of the mandible', American Journal of Diseases of Children 48, 541-7.
Shprintzen, R.J. \& Singer, L., 1992, 'Upper airway obstruction and the Robin Sequence', International Anesthesiology Clinics 30, 109-114. PMid:1468802

Singer, L. \& Sidoti, E.J., 1992, 'Pediatric management of Robin sequence', The Cleft Palate-Craniofacial Journal 29, 220-223. http://dx.doi.org/10.1597/1545-1569 (1992)029<0220:PMORS>2.3.CO;2

Smith, M.C. \& Senders, C.W., 2006, 'Prognosis of airway obstruction and feeding difficulty in the Robin sequence', International Journal of Pediatric Otorhinolaryngology 70 319-324. http://dx.doi.org/10.1016/j.ijporl.2005.07.003, PMid:16112206

St-Hilaire, H. \& Buchbinder, D., 2000, 'Maxillofacial pathology and management of Pierre Robin sequence', Otolaryngologic Clinics of North America 33, 1214-1256. http://dx.doi.org/10.1016/S0030-6665(05)70279-6

Taylor, M.R.G., 2000, 'The Pierre Robin sequence: A concise review for the practicing pediatrician', The Journal of Pediatrics 22, 125-130. http://dx.doi.org/10.1542/ pir.22-4-125

Vegter, F., Hage, J.J. \& Mulder, J.W., 1999, 'Pierre Robin syndrome: Mandibular growth during the first year of life', Annals of Plastic Surgery 42, 154-157. PMid:10029479

Wagener, S., Rayatt, S.S., Tatman, A.J., Gornall, P. \& Slator, R., 2003, 'Management of infants with Pierre Robin sequence', The Cleft Palate-Craniofacial Journal 40 180-185. http://dx.doi.org/10.1597/1545-1569(2003)040<0180:MOIWPR>2.0.CO;2

Whitaker, I.S., Koron, S., Oliver, D.W. \& Jani, P., 2003, 'Effective management of the airway in the Pierre Robin syndrome using a modified nasopharyngeal tube and
pulse oximetry', British Journal of Oral and Maxillofacial Surgery 41, 272-274. pulse oximetry', British Journal of Oral and Maxillofa
http://dx.doi.org/10.1016/S0266-4356(03)00100-1 
INFORMATION and CONSENT FORM

\section{Maxillo-Facial and Oral Surgery Kaak-, Gesig- en Mond-Chirurgie}

Patient's surname/Pasiënt se van:

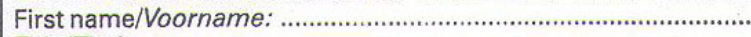

Title/Titel:

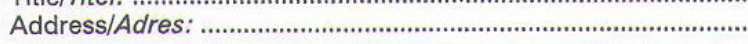

Profession and/or business/

Beroep en/of besigheid:

Work address/Werksadres:

Tel (Home/Huis): (Work/Werk):

ID number/nommer: ..................................................................

Date of birth/Geboortedatum:

Age/Ouderdom: .

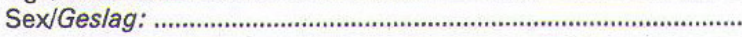

Patient a child/Pasënt 'n kind:

Name of parent and title

Naam van ouer en titel:

Profession of father:

Beroep van vader: .

Profession of mother:

Beroep van moeder:

Medical Aid/Mediese Fonds:

Name \& postal address, person responsible for account

Naam \& posadres, persoon verantwoordelik vir rekening .........

(1)

Referring doctor (compulsory)

Verwysende dokter (verpligtend):

Adress/Adres:

House Medical Practitioner/

Huisgeneesheer:

House Dental Practitioner/

Huistandarts:

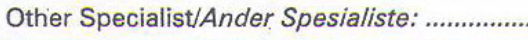

Medical History

Mediese Geskiedenis:

\section{AIDSIVIGS}

Infective conditions

Hypertension/Hipertensie

Angina Pectoris Liver problems/Lewerprobleme

4ngina Pectoris Miocard. Infarct//Hart Infarkt.

Asthma/Asma Ear-Nose-Throat/Oor-Neus-Keel

Stroke/Beroerte

Haemorrhage
Bloedingsneigings

Bloedingsneigings
Diabetes/Diabeet

Diabetes/Diabeet
Epilepsy/Epilepsie

Porphyria/Porfirie

$\begin{array}{ll}\text { Rheumatic Fever } \\ \square & \text { Rumatiekoors } \\ \text { P } & \text { Psychological treatment }\end{array}$

$\begin{array}{ll}\text { R Reumatic Fever } \\ \square & \text { Rumatiekkoors } \\ \text { Psychological treatment }\end{array}$

Allergies:

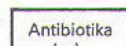

Elastoplast

\section{Scoline} Skolien

\section{Other}

Ander

Previous operations (all)/

Vorige operasies (almal):

Past 2 yrs to doctor/hospital

Laaste 2 jr na dokter/hospitaal:

Serious illness/Ernstige siekte:

\begin{tabular}{|c|c|c|c|c|}
\hline \multicolumn{2}{|c|}{ Pregnant/Swanger: } & Yes/Ja & No/Nee & \\
\hline $\begin{array}{l}\text { Medicine: } \\
\text { Medisyne: }\end{array}$ & $\begin{array}{l}\text { Cortisone } \\
\text { Kortisoon }\end{array}$ & $\begin{array}{l}\text { Insulin } \\
\text { Insulien }\end{array}$ & $\begin{array}{l}\text { Blood pres } \\
\text { Bloeddruk }\end{array}$ & $\begin{array}{l}\text { Other } \\
\text { Ander }\end{array}$ \\
\hline
\end{tabular}

Other problems/

Ander probleme:
INFORMASIE EN TOESTEMMINGSVORM

Konsultant/Dokter:

Consultant/Doctor:

\section{Family history/}

Familie geskiedenis:

Main Complaint

Hoofklagte:

Did an acquaintance/friend reccommend

me to you?

Yes No

CONSENT (Treatment and payment)

TOESTEMMING (Behandeling en betaling)

I herewith give the surgeon permission to examine me / my wife / my child and, on his recommendation and in consultation with me / my wife to proceed with the necessary treatment. I also undertake to pay the full amount of professional fees (which shall not be according to the scale of benefits), which result from consultation, examination material(s) and treatment(s), as soon as possible, and I accept that interest will be charged on outstanding accounts ( +120 days)

Hiermee gee ek toestemming dat die chirurg myself / my vrou / my kind mag ondersoek en op sy aanbeveling en toestemming deur myself / my vrou die nodige verdere behandeling mag voortsit. Hiermee aanvaar ek ook dat ek alle professionele gelde (wat nie volgens voordeleskaal is nie) wat ontstaan deur die konsultasie, ondersoekmateriale en behandeling/s so spoedig as moontlik ten volle sal vereffen en dat ek kennis daarvan neem dat rente gehef sal word op uitstaande bedra (+ 120 dae).

Date/Datum

Signature/Handtekening

\section{CONSENT (Research)}

TOESTEMMING (Navorsing)

I herewith give my consent to all examination materials ( $X$ ray's, photos, models, etc) and examination reports of myself / my wife / my child, to be used for research and publication.

Hiermee gee ek toestemming dat alle ondersoekmateriale (Röntgenbeelde, foto's, modelle, ens) en ondersoekverslae van myself / my vrou / my kind gebruik mag word vir navorsing-en publikasiedoeleindes.

Date/Datum

Signature/Handtekening

Date of admission: Date of dischárge

Datum van opname: Datum van ontslag:

\begin{tabular}{c|c|c|c|}
$\begin{array}{c}\text { Out patient } \\
\text { Buitepasiënt }\end{array}$ & $\begin{array}{c}\text { In patient } \\
\text { Binnepasiënt }\end{array}$ & $\begin{array}{c}\text { Out patient } \\
\text { Buitepasiënt }\end{array}$ & $\begin{array}{c}\text { In patient } \\
\text { Binnepasiënt }\end{array}$ \\
\hline & & & \\
\hline
\end{tabular}

